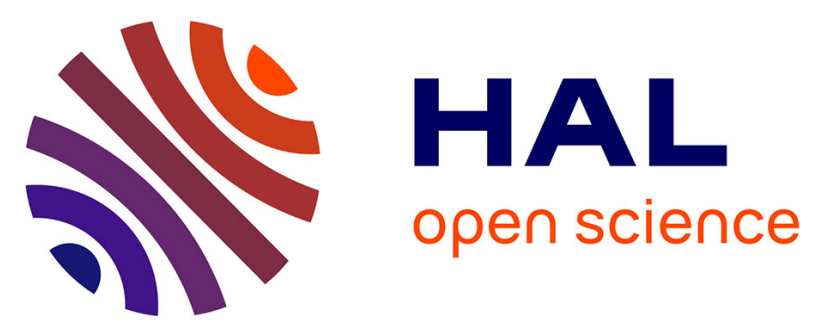

\title{
Stratigraphy, palaeoclimatic context and fossils of the Southern Rub Al Khali (the Empty Quarter): geological-surveying results of a geo-archaeological survey around the area of Maitan in the Sultanate of Oman
}

\author{
M. Al Kindi, M. Pickford, D. Gommery, A. Qatan
}

\section{To cite this version:}

M. Al Kindi, M. Pickford, D. Gommery, A. Qatan. Stratigraphy, palaeoclimatic context and fossils of the Southern Rub Al Khali (the Empty Quarter): geological-surveying results of a geo-archaeological survey around the area of Maitan in the Sultanate of Oman. Historical Biology, 2020, pp.1-22. 10.1080/08912963.2020.1717485 . hal-02462095

\section{HAL Id: hal-02462095 \\ https://hal.science/hal-02462095}

Submitted on 19 Nov 2020

HAL is a multi-disciplinary open access archive for the deposit and dissemination of scientific research documents, whether they are published or not. The documents may come from teaching and research institutions in France or abroad, or from public or private research centers.
L'archive ouverte pluridisciplinaire HAL, est destinée au dépôt et à la diffusion de documents scientifiques de niveau recherche, publiés ou non, émanant des établissements d'enseignement et de recherche français ou étrangers, des laboratoires publics ou privés. 
Stratigraphy, Palaeoclimatic Context and Fossils of the southern Rub al Khali (the Empty Quarter): Geological-surveying Results of a Geoarchaeological Survey around the area of Maitan in the Sultanate of Oman

\author{
Al Kindi M. ${ }^{1}$, Pickford M. ${ }^{2}$, Gommery D. ${ }^{3}$ \& Qatan A.
}

Mohammed Al Kindi, Earth Sciences Consultancy Centre - Muscat malkindi@gmail.com

Martin Pickford, UMR 7207 CR2P - MNHN-CNRS-SU, Muséum national d'Histoire naturelle, Paris

martin.pickford@mnhn.fr

Dominique Gommery, UMR 7207 CR2P - MNHN-CNRS-SU, Sorbonne Université, Paris dominique.gommery@sorbonne-universite.fr

Ahmed Qatan, Petroleum Development Oman ahmadqatan285@gmail.com 


\begin{abstract}
During January 2019, a team of geologists and archaeologists conducted a survey in the area north of the desert village of Maitan, located at the Southern border of the Sultanate of Oman, following reports from local people who found ancient lithic tools in the area. This paper summarizes the geological work in the area and introduces a brief about the archaeological interest in the area. The region is dominated by extensive, tall linear dunes overlying an incised Eocene marine limestone plateau about 280-300 metres above sea-level. Above the limestone plateau, the interdunal areas often expose various recent deposits including: palaeo-regolith and epikarst deposits, fluvial conglomerates, gypsum «playa-like» deposits, aeolianites, semiconsolidated dunes, sand and silt with gypsum-roses, calcareous tufa and loose sand. The sediments indicate the prevalence of largely arid and hyper-arid conditions, with brief intervals of relatively humid conditions, during which humans and their livestock probably inhabited the region. The presence of abundant mill stones, grindstones and pestels and mortars, along with fossilised animal bones, beads and other ornaments, scrapers, blades and other instruments, speaks for prolonged occupation of the area during pre-historic times. The survey revealed the presence of Late Palaeolithic, Middle and Late Neolithic sites. The discovery of this new archaeological area provides extraordinary information about the middle Holocene peopling of this region, about which little was previously known. Comparisons with known sites in the Rub al Khali desert, scattered along the southern edge through Oman and Yemen but also in Saudi Arabia, show an incredibly high presence of living and moving human populations in an area which now seems so inhospitable.
\end{abstract}

\title{
Location
}

Maitan is a small desert village located in the northern side of the City of Al Mazyonah (Figure 1). The village is close to the triple-border junction between Oman and both Yemen and Saudi Arabia (Figure 2). The area north of Maitan, Oman, is part of the Rub Al Khali (Empty Quarter), a vast desert extending from Yemen in the south, to the United Arab Emirates more than 1,000 km to the north-east and covering a significant part of central and eastern Saudi Arabia and western Oman. 
Being located near the triple-border junction between Oman, Yemen and Saudi Arabia, the area is often inspected by the military. For this reason, it is mandatory to liaise with the local governor in Maitan while visiting any of the locations mentioned here and to obtain research permits to rove in this area. Local people from Maitan refer to the linear dunes as Urq (singular) and Uruq (plural). This Arabic term has also been scientifically adopted to refer to similar structures, with different spellings, including Erg and Urg. The linear dunes north of Maitan are named Uruq Al Hadd. The southernmost linear dunes are called Urq Jadailah and Urq Shuayt, whereas the interdunal areas between these Uruq are called Shaq (for masculine names) and Shaqat (for feminine names). Most of the surveying efforts were focused in Shaq Shuayt and Shaqat Jadailah (Figure 3).

\section{Geology of the area and Previous Work}

The region is dominated by extensive, tall linear dunes overlying an incised Eocene marine limestone plateau about 280-300 metres above sea-level. The dunes form sub-parallel linear sand ridges oriented from north-south to north-north-east to south-south-west, separated from each other by interdune "Urq or Shaq " ("corridors" or "streets" in English). These interdunal areas are generally flat and their floors comprise a variety of rock types ranging from Eocene limestone, to palaeo-regolith and epikarst deposits, fluvial conglomerates, gypsum " playa-like » (sabkha) deposits, aeolianites, semi-consolidated dunes, sand and silt with gypsum-roses, calcareous tufa, interdune arcuate silt-drapes and loose sand. Some of the star dunes and linear sand ridges are well over 100 metres high, but the post-Eocene sediments exposed in the interdune corridors are generally less than 5 metres thick and are discontinuous in plan and section. The stratigraphic succession has thus been reconstructed from a large number of discrete outcrops.

Little previous work has been published on the post-Eocene rocks of the area, the main references being the geological maps Ramlat Rakhawat NE 39-03/07/11 and Abl Ghamghimah NE 39-04 (Berthiaux et al. (1992). A relevant publication on the neighbouring area is by Matter et al. (2014) who studied Pleistocene to Recent deposition in the Rub Al Khali of Saudi Arabia close to the Yemen and Oman borders. The Maitan area was first visited in January, 2018, guided 
by local residents of Maitan: Humaid Al Huraizi and his son Said Al Huraizi. People from Maitan have been finding and collecting various artifacts and fossils, including mills, mortars, tethering stones and ostrich eggs, but no proper survey of the area was conducted before.

Most of the geological and archaeological surveying was focused in Shaqat Jadailah (Figure 4). We, therefore, refer to the main sites surveyed in this area as SQJ. SQJ-2 was the first site reported to us by local people. The site is part of a large depression or bowl, about $3.5 \mathrm{~km}$ by 3 $\mathrm{km}$ in diameter, surrounded by large sand dunes on almost all sides. The depression can be accessed via two narrow entrances in the NE and SW. The recent deposits indicate that ancient springs existed in the bowl.

\section{Stratigraphy of the Uruq Al Hadd}

The stratigraphic succession can conveniently be subdivided into three major phases, comprising, from the base upwards: 1) Eocene marine bedrock substrate, 2) possibly Mio-Pliocene palaeoland surface and associated conglomerate, 3) Pleistocene-to-Extant aeolian-dominated desert phase with playa interbeds. Neolithic humans (and their small livestock?) could survive in the region during a relatively humid interval, during which gypsiferous playa deposits accumulated. These gypsum deposits pre-date or were contemporary with human occupation (ca 8,000 years ago).

\section{Eocene Limestone}

The bedrock in the western sector of the Rub Al Khali is comprised of Eocene marine limestone (Figure 6) containing flint nodules (Figure 7) attributed to the Dammam Formation (Berthiaux et al. 1992). Relief in the area north and east of Maitan exposes as much as 50 metres of wellbedded white fossiliferous limestone with flint nodules. The upper surface of the limestone shows abundant fissures which contain indurated epikarst sediment of a reddish-pinkish colour

(Figure 8), some fissures penetrating up to a metre into the bedded limestone. In places the fissure fillings are contiguous with a discontinuous thin layer (up to $10 \mathrm{~cm}$ thick) of palaeoregolith, varying from deep red to brown in colour, but over much of the outcrop, the limestone 
surface is bare. The fissure fillings and regolith are possibly of Miocene age or younger, although no direct evidence of their age has been found.

\section{Mio-Pliocene fissure fillings, palaeoregolith and conglomerate}

Lime-cemented conglomerate with well-rounded pebbles occurs sporadically in the survey area (Figure 9). Its red matrix resembles that of the palaeo-regolith, indicating the possibility that it is of the same age, perhaps Miocene, although no direct evidence has been found to confirm this. Further east and north-east, Berthiaux et al. (1992) mapped extensive outcrops of Miocene sediments which they attributed to the Shisr Formation or Marsawdad Formation, for which they estimated a Mio-Pliocene correlation. The occurrences in the study area could represent the feather-edge of the formation where outcrops become thin and discontinuous.

\section{Post-regolith Phase}

Following maturation of the post-Eocene landscape, represented by a thin, but widespread limecemented palaeo-regolith and patchy outcrops of fluviatile conglomerate, there started a phase of wind-dominated activity resulting in widespread aeolian sand deposition (Figure 10), some of which became indurated to form semi-consolidated dunes, and in cases, even of well-cemented aeolianites. Much of the sand which accumulated during this phase was subsequently remobilised and has contributed to the extant dune system in the Rub Al Khali and continues to be reworked as superficial mobile sands covering the dunes and the interdune depressions and corridors (Urq and Shaq).

There followed a widespread phase of deposition of gypsiferous clays/silts in playa-like (sabkha) settings (Figure 11). These gypsum-rich silts are widespread but discontinuous in outcrop (Figure 12), and some may extend under the main sand ridges of the Rub Al Khali. In places, in particular near the major concentration of Neolithic tools, ornaments and fauna, $15 \mathrm{~km}$ north-north-west of Maitan, the gypsum forms low domes rich in rhizoliths suggestive of the existence of surface springs at the time of playa conditions. The sand underlying the gypsum is variably cemented, and in places shows important development of desert roses (sand-rich gypsum crystals up to 10 $\mathrm{cm}$ in diameter) (Figure 13). 
In places, often associated with the "spring mounds " there are thin occurrences of hard calcareous tufa rich in impressions of plant roots and stems, probably the sites of localised runoff from spring mounds (Figure 14). Many artefacts of different ages have been found around these mounds (Figure 15).

\section{Post-Neolithic sub-phase}

The post-Neolithic sub-phase of sedimentation in the Uruq Al Hadd region is represented by unconsolidated sands, often with scattered artefacts on top of sand, and arcuate outcrops of silt which accumulated in interdune depressions as the result of infrequent rainstorms in the region. Concave silt drapes form rapidly in interdune depressions while the rain is falling and for a few days afterwards when water that fell on nearby dunes drains slowly through the sand into the depressions, carrying silt and clay with it (Figure 16). If the depressions are formed in dune sand (Figure 17) the water generally drains away from them rapidly subterraneously (a few days or weeks) (often the case in the Rub Al Khali) but if the floor of the depression is impermeable (for example solid bedrock), the water can persist for much longer (several months) until it evaporates (not observed in the Rub Al Khali).

\section{Fauna from the Uruq Al Hadd}

The Neolithic occurrences north of Maitan not only contain a rich and diverse assemblage of stone implements, but they are also associated with marine and terrestrial faunal remains and plant impressions. The aim of this section is to describe the marine elements utilised for manufacturing decoration and other objects, such as buttons, and to discuss the terrestrial faunal elements in order to provide an idea of the food resources utilised by the communities that made the stone tools. Some of the plant remains are possibly identifiable, but detailed studies would need to be undertaken by a palaeobotanist experienced in the study of plant impressions and roots. The marine fossils associated with the stone tool assemblages are of two kinds, a) Eocene fossils from the local outcrops of limestone, some of which appear to have been used as ornaments (e.g. bivalves with ribbed shells) and some possibly collected as " interesting " stones (large gastropod internal molds, not illustrated herein), and b) imported recent shells used as 
ornaments (e.g. small and large cowrie shells and other marine gastropods and bivalves). For instance, the ancient people of Uruq Al Hadd manufactured a bead from a small fossil echinoid. It is stressed that the faunal remains associated with the Neolithic implements were found in surface context, i.e. no excavation was undertaken. All of the terrestrial elements are wellfossilised and none of them show signs of burning.

\section{Marine Fauna}

In Uruq Al Hadd, a moderate variety of extant species of marine gastropods and bivalves are found in association with Neolithic implements. Cowrie shells (14 specimens) dominate the assemblage, and comprise at least four taxa, one very large (Figure 18) and three smaller ones (Figure 19, Figure 20 and Figure 21). Other gastropod taxa represented in the collection comprise Morula granulata (one eroded specimen, Figure 21F), Oliva bulbosa (one individual, Figure 21), one specimen each of Nerita textilis (Figure 22) and Nerita albicilla (Figure 23), Volvarina spp. (four specimens, Figure 22), Ancilla ovalis (two specimens, Figure 22), and various fragments of marine bivalves, mostly Chlamys sp. (Figure 21, and Figure 24 to Figure 26) but also one possible specimen of Anadara sp (Figure 26). All the taxa identified occur widely in the Arabian Sea, the Sea of Oman and the Persian Gulf (Dance, 1998). In addition there is a single bead made from a small fossilised sea urchin, possibly of Eocene age (Figure 27). Moreover, one of the ornaments found is made from a fragment of bivalve shell (Figure 28).

\section{Terrestrial Fauna}

The terrestrial faunal remains associated with Neolithic implements in the Rub Al Khali are dominated by ostrich eggshell fragments (Figure 29, 30,31), of which dozens of specimens were collected from various sites (Table 1). Second in dominance are remains of a small bovid, possibly a goat, which is smaller than the goats kept in Oman today (Figure 39). Third are lagomorph bones (Figure 38). There are also rare remains of a medium-sized bovid somewhat larger than the " goat » and two chelonian scutes (Figure 37). 


\section{Struthionidae}

The vast majority of ostrich eggshell fragments from the Uruq Al Hadd match in shell thickness and surface morphology (details of pore structures) with eggs of Struthio camelus, the extant ostrich (Figure 30 to Figure 32) (a recent eggshell from the dunes west of Jebel Hafeet, Buraimi, is $1.9 \mathrm{~mm}$ thick). One fossil specimen from SQJ-5, however, is considerably thicker than any modern ostrich eggshells (Figure 300 and Figure 32), but agrees in dimensions with specimens of extinct ostrich species Diamantornis laini and Struthio daberasensis (Pickford et al. 1995; Senut \& Pickford, 1995; Pickford, 2014). The specimen is deeply weathered on its outer surface and does not show any obvious pore structures, so it is unlikely to belong to Struthio daberasensis which usually shows clear pore complexes. Diamantornis laini, in contrast, has large areas of smooth shell interrupted by circular pore complexes, and it is not unusual to find fragments that have no pores preserved on them Pickford, 2014; Bibi et al. 2005).

Both Struthio daberasensis (4-3 Ma) and Diamantornis laini (8-7 Ma) are extinct. The presence of either of these species at the Neolithic sites of the Rub Al Khali implies either that humans may have collected fossilised eggshell fragments for fabrication of ornaments or that the eggshells eroded from subjacent Mio-Pliocene deposits and are " accidentally » associated with the stone tools (in the same way that some of the Eocene marine shells are).

It is worth pointing out that abundant Diamantornis laini eggs have been reported from Late Miocene deposits in the United Arab Emirates, $700 \mathrm{~km}$ to the north-north-east of the Uruq Al Hadd (Bibi et al. 2005, Louchart et al. unpublished).

Several perforated beads manufactured from ostrich eggshell were collected at the same sites as the unworked eggshell fragments, notably in the area between SQJ-1 and SQJ-2 (Figure 33), where the ancient springs might have existed (see Figure 4, and Figure 29 to Figure 32). The presence of possible bead shapers at the same localities (Figure 34) indicates that Neolithic people may have manufactured their beads on site.

Three ostrich eggshell beads from Uruq Al Hadd yield evidence that the Neolithic people probably selectively collected fossil eggshells to manufacture beads. These three specimens show evidence of dissolution of the outer surface of the eggshells prior to drilling to make beads (Figure 35). There is also evidence that dissolution processes continued after the beads had been made. 
Other beads appear to have been made on unweathered eggshells, indicating either that the eggshells were fresh when drilled, or were fossilised but had not been exposed to weathering before the drilling took place (Figure 36).

\section{Chelonia}

The area near SQJ-4 yielded two fragments of chelonian scute. The fragments are small and cannot be identified below the ordinal level, but they are compatible with terrestrial tortoises (Testudinidae) (Figure 37).

\section{Lagomorpha}

Two localities SQJ-2 and SQJ-4 yielded lagomorph specimens. The distal humerus from SQJ-4 is slightly smaller than that of the extant domestic rabbit and the first phalanx from locality SQJ-2 is from an unknown ray, but is compatible with the rabbit (Table 2, Figure 38).

\section{Bovidae}

Bone and tooth fragments of two species of ruminants are associated with Neolithic implements in the Rub Al Khali; a) a bovid somewhat smaller than the extant domestic goats of Oman (Table 3, Table 4, Figure 39 and Figure 40), and b) a medium-sized species which is poorly represented but could be about the size of a cow. Given the poor preservation of the second taxon, it is not possible to determine whether it represents a wild ruminant (e.g. Oryx) or a domestic animal (e.g. cow).

The bovid tooth fragments from Uruq Al Hadd are too poorly preserved to identify confidently, but they are hypsodont and are compatible in dimensions to the small bovid at the same sites.

\section{Discussion and Conclusions}

\section{Stratigraphy of the Uruq Al Hadd}

The Uruq Al Hadd area in the west of Oman close to the Yemen and Saudi Arabia borders is part of the Rub Al Khali (Empty Quarter) Desert. The region is dominated by extensive linear dunes overlying an Eocene marine substrate, and associated with minor layers of Mio-Pliocene deposits 
and more extensive but thin layers of aeolianite and playa deposits exposed in the interdune flats (or Uruq). There is a major occurrence of Neolithic artefacts and faunal remains $15 \mathrm{~km}$ northnorth-west of Jadailah.

The post-regolith sediments in the Uruq Al Hadd region indicate the prevalence of largely arid and hyper-arid conditions with predominantly aeolian transport and deposition, with brief intervals of relatively humid conditions (probably steppe, less likely savannah) during which humans and their livestock inhabited the region. During these slightly more humid conditions, there were probably surface springs (or shallow wells) where fresh water was available. Rhizoliths in gypsum mounds, and plant impressions in thin layers of calcareous tufa attest to the presence of vegetation growing in the region. Whilst Matter et al. (2014) reported the presence of freshwater gastropods and bivalves in « palaeolake » deposits at altitudes between 530 and 230 metres in the Saudi Arabian sector of the Rub Al Khali, none were observed during the present survey in Oman. The authors interpreted the mollusc-bearing deposits as evidence for the existence of a series of small palaeolakes in the region, but no signs of fully lacustrine deposits were observed during our survey in the Omani sector of the desert. Nevertheless it is inferred that during the phase of widespread gypsiferous clay-silt deposition in the interdune corridors, the water table must have been quite close to the palaeoland surface. Apart from that phase, it seems that during the Pleistocene and Holocene, the water table was usually well below the land surface. Further north in Saudi Arabia, there may well have been small perennial ponds and lakes in the Rub Al Khali during the Pleistocene and Recent as inferred by Matter et al. (2014) but our survey suggests that such was not the case in the Omani sector of the desert that was surveyed in January 2019.

\section{Fauna from the Uruq Al Hadd}

The marine and terrestrial faunal remains associated with Neolithic implements and ornaments in the south-western sector of the Rub Al Khali, yield interesting information concerning the animals that the Neolithic people could have exploited. At the Neolithic occurrences at Uruq Al Hadd, a variety of marine shells was utilised for the manufacture of beads, other ornaments, and even of a button-like object. All the taxa represented in the samples are widespread in the seas 
around the Arabian Peninsula (Dance, 1998) but they were carried at least $250 \mathrm{~km}$, the closest coast to the Neolithic localities being that of the Dhofar to the south. In addition to the extant species utilised, there is a bead made from a fossilised sea-urchin, probably of an Eocene species. Ostrich eggshell fragments are common, and some have been fashioned into beads, suggesting not only that eggs were possibly eaten, but also that they were the basis for fabricating ornamentation. Some of the beads appear to have been made from fossilised eggshell fragments. The presence of chelonian remains opens up the possibility of opportunistic gathering of wildlife for consumption, but it is also possible that the remains are secondarily associated with the lithic implements (i.e. that some specimens could have died naturally close to the occupation site). The lagomorph remains could represent the residues from hunting of wild animals, but the small bovids could represent small domesticated goats. The medium-sized ruminant fossils are too poorly preserved to identify - they could be from a domesticated animal or from a wild species such as the Oryx.

Finally, the presence of a very thick struthious eggshell fragment at one of the sites is of interest, but it is not known whether the specimen was collected by Neolithic peoples for fashioning into a bead (no Mio-Pliocene deposits occur at the site so it is deduced that it did not occur at the site naturally). Similar eggshells are known to occur in Late Miocene deposits of the United Arab Emirates, and it is not impossible that they occur closer to the Uruq Al Hadd Neolithic sites, because Miocene and Pliocene deposits have been mapped in the Rub Al Khali to the north-east of the survey area (Berthiaux et al. 1992). Long-distance transport of the eggshell is not out of the question, as among the marine remains found at the site there are shells of Cypraea (large and small species), other extant marine gastropods, and bivalves, either gathered by the Neolithic people themselves, or traded over at least $250 \mathrm{~km}$ (nearest distance to the sea). The presence of a button-like object manufactured from durable bivalve shell suggests that tissues may have been fastened by a system of buttons and button holes.

The presence of abundant mill stones, grindstones and pestles and mortars, along with fossilised animal bones, beads and other ornaments, together with a rich and varied stone tool assemblage running to hundreds of points, scrapers, blades and other instruments, speaks for prolonged occupation of the Uruq Al Hadd during Neolithic times. The area could have been inhabited on a 
seasonal basis, or could have had a permanently settled human population. Both scenarios suggest that the area was somewhat more humid than it is today, which accords with the abundance of gypsiferous playa deposits with spring mounds that occur in the region

\section{Palaeoclimate in Uruq Al Hadd}

During the beginning of the Pleistocene, the Rub Al Khali area was most likely covered by a plain of old alluvium (McClure, 1978). The vast and massive dune sheets and ridges in the area today were gradually deposited during the dry periods of the Pleistocene and Holocene (Kumar \& Abdullah, 2011). These epochs were characterized by alternating humid and arid phases. During the humid wet periods, lake beds were deposited in the area. Edgell (1990) discussed a provisional yet detailed climate history beginning during the Early Pleistocene to Holocene and dividing this span of time into 16 alternating humid and arid climate phases in the region. The duration of these alternating climate phases varies from a few hundred years to a few thousand years. More recent work based on optical dating chronologies indicate that rapid accretion of sand dunes began in Mid-Late Holocene followed 5,000 and 2,800 years B.P. by rapid phases of dune deposition (Bray \& Stokes, 2003). Major humid periods were 35,000-25,000 years B.P. and 10,000-6,000 years B.P. and abrupt change from a humid to arid phase began approximately 6,000 years B.P., leading to the formation of aeolian sediments in large bed forms (Bray \& Stokes, 2004).

A recent study using palynological and mineralogical proxies along with large numbers of radiocarbon dates describes the impact of the last deglaciation and the Holocene climate change on human occupation and distribution in Rub Al Khali (Lézine et al. 2010). Lézine et al. 2010 argue that many archaeological sites, characterized by scattered stone artefacts, ostrich eggshells and bones around hearths, are related to this lacustrine phase, which culminated around 10,0008000 years before present (B.P.) in the lowland deserts before the lakes progressively dried up. The last record of fresh-water bodies date back 7,300 years B.P. at Shabwa (Yemen) and 7,500 years B.P. at Al Haid (Oman). Then, fresh-water was probably available only from seasonal runoff from adjacent highlands, where palaeolakes persisted into the late Holocene. The recent rainfall that occurred in mid-2018 in Dhofar, following a number of cyclonic storms that struck 
the areas, led to the formation of temporary lakes on the eastern side of Rub Al Khali (Figure 41), and the area was then progressively covered by green vegetation, which lasted a few months after the cyclonic events, making the area very attractive for grazing.

The results from our study also show that the area around Uruq Al Hadd in Rub Al Khali was occupied at least three times, during Late Palaeolithic (around 10,000 years B.P.), Middle Neolithic (8,500-6,500 / 6,200 years B.P.) and possibly during the Late Neolithic Period (6,5005,700 years B.P.). This broadly coincides with the identified ages of wet periods in Arabia.

The most prospective cluster of sites in Shaqat Jadailah was probably deposited around a former spring, as suggested by the linear distribution of gypsum mounds in the area (Figure 42). These linear mounds might have been positioned along a blind fault system that connected shallow or deep aquifers to the surface.

\section{Future Perspectives}

Due to the scarcity of prehistoric sites detected in the Omani Rub al Khali until now, it is important to proceed with research in this area in the next seasons. The area around the Ramlat Jadailah constitutes an important resource for the comprehension of both Pleistocene and Holocene aspects of the Southern Arabia prehistory and the multi-disciplinary expedition during January, 2019, proved that cooperation between geologists, palaeontologists and archaeologists is very useful for achieving this purpose.

\section{Acknowledgements}

We are sincerely thankful with unlimited support and guidance from the Ministry of Heritage and Culture, represented by:H.E. Salim Al Mahrouqi, Undersecretary for Heritage Affairs, Mr. Sultan Al Bakri, director of the Department of Excavation \& Archaeological Studies, Mr. Ali Al Mahri, Directorate of Dhofar, Mrs. Raiya Al Kindi, Assistant Director General, Museums Department and Mrs. Sumia Al Busaidi, Department of Excavation \& Archaeological Studies.

We thank the archaeological team that accompanied us in this trip for their very productive discussions: Maria Pia Maiorano, Vincent Charpentier, Jérémie Vosges, Grégor Marchand and Federico Borgi. We are also very grateful to the great support provided by the people of Maitan 
throughout the survey period. We would like to specifically thank Said Al Huraizi for guiding us to many important locations in the area of interest. 


\section{References}

Berthiaux, A., Platel, J.P. \& Chevrel, S. (1992). Geological Map Abl Ghamghimah Sheet NE 39-04, Oman 1: 250,000 and Explanatory Notes. Ministry of Petroleum and Minerals, Directorate of Minerals, Muscat, Sultanate of Oman. Map and $36 \mathrm{pp}$.

Bibi, F., Shabel, A.B., Kraatz, B.P. \& Stidham, T.A. (2005). New ratite (Aves: Palaeognathae) eggshell discoveries from the Late Miocene Baynunah Formation of the United Arab Emirates, Arabian Peninsula. Palaeontologica Electronica. Vol. 9, Issue 1; 2A:13p, 554KB; http://palaeo-electronica.org/paleo/2006 1/eggshell/issue1 06.htm.

Bray, H.E. \& Stokes, S. (2003). Chronologies of Late Quaternary barchan dune reactivation in the southeastern Arabian Peninsula. Quaternary Science Reviews, 22: 1027-1033.

Bray, H. E. \& Stokes, S. (2004). Temporal patterns arid-humid transitions in the southeastern Arabian

Edgell, H.S. (1990). Evolution of Rub' al Khali desert. Jour. King Abdul Aziz University, Earth Sciences, 34, Special Issue, 1st Saudi Arabia Symposium on Earth Sciences, Jeddah (1989), pp. 109-126.

Kumar, A. \& Mahmoud, M.A. (2011). An overview of Origin, Morphology and Distribution of Desert Forms, Sabkhas and Playas of the Rub. Al- Khali Desert of the Southern Arabian Peninsula, Earth Science India 4: 105-135.

Lézine, A-M, Robert, C., Cleuziou, S., Inizan, M-L., Braemer, F., Saliège, J-F., Sylvestre, F., Tiercelin, J-J., Crassard, R., Méry, S., Charpetier, V. \& Steimer-Herbert, T. (2010) Climate change and human occupation in the southern Arabian lowlands during the last deglaciation and the Holocene. Global and Planetary Change, 72: 412-428.

Louchart, A., Bibi, F. \& Stewart, R. (Unpublished). The birds of the Late Miocene Baynunah Formation, Abu Dhabi Emirate. In: Bibi, F., Kraatz, B, Beech, M. \& Hill, A. (Eds) Sands of Time: Late Miocene Fossils from the Baynunah Formation, U.A.E. Cham, Switzerland, Springer, Chapter 9, 32 pp. (available online).

Marks, A. E. (1976). Glossary. In Marks, A. E. (Ed.), Prehistory and paleoenvironments of the Central Negev, Israel, volume 1: the Avdat/Aqev area part 1 (pp. 371-383). Southern Methodist University Press, Dallas 
Matter, A., Neubert, E., Preusser, F., Rosenberg, T. \& Al-Wagdani, K. (2014) Palaeo-environmental implications derived from lake and sabkha deposits of the southern Rub' al-Khali, Saudi Arabia and Oman. Quaternary International, 2014: 1-12. http://dx.doi.org/10.1016/j.quaint.2014.12.029.

McClure, H. A. (1978). Ar Rub’ Al Khali. In: S.S. Al-Sayari\& J.G. Zölt (Eds), Quaternary Period in Saudi Arabia. Springer-Verlag. 334 p. Peninsula based on optical dating. Geomorphology, v.59, pp. $271-280$.

Pickford, M. (2014). New Ratite Eggshells from the Miocene of Namibia. Communications of the Geological Survey of Namibia, 15: 70-90.

Pickford, M., Senut, B. \& Dauphin, Y. (1995). Biostratigraphy of the Tsondab Sandstone (Namibia) based on gigantic avian eggshells. Géobios, 28 (1): 85-98.

Senut, B. \& Pickford, M. (1995). Fossil eggs and Cenozoic continental biostratigraphy of Namibia. Palaeontologia Africana, 32: 33-37.

Sultan, M., Sturchio, N., Alsefry, S., Milewski, A., and Becker, R., Nasr, I. \& Sagintayev, Z. (2008). Geochemical, isotopic, and remote sensing constraints on the origin and evolution of the Rub Al Khali aquifer system, Arabian Peninsula. Journal of Hydrology. 356. 70-83. 10.1016/j.jhydrol.2008.04.001.

Thesiger, W. (1959). Arabian Sands. E.P. Dutton and Company, Inc, New York. 


\section{List of figures.}

Figure 1. Satellite Map of Oman showing the study area in the south-eastern side of the Rub Al Khali, between 280-300 metres above sea-level.

Figure 2. The study area (shaded here in yellow) is located north of the Village of Maitan in the triple border junction between Oman and both Yemen and Saudi Arabia. Detailed observations were mostly focused on the western side of this shaded zone. The satellite image is modified from Google Earth.

Figure 3. The locations of Shaq Shuayt and Shaqat Jadailah in Uruq Al Hadd Linear Sand Dunes north of Maitan. The satellite image is modified from Google Earth.

Figure 4. The main sites in Shaqat Jadailah (SQJ), where the greatest concentration of Neolithic artefacts was found and where most of the surveying efforts were focused. These sites are located within a large bowl that could be easily accessed only through two narrow zones in the NW and SW. The silty gypsum mounds and flats in the bowl as well as the tufa deposits indicate the presence of ancient springs in this area. The silty gypsum deposits mostly appear white in this satellite image, these are often associated with tufa deposits, whereas the consolidated sand dunes are often located on the flanks of the existing large sand dunes in the area. SQJ-2 was the first site reported by local people, where grind stones and mills were found. The satellite image is modified from Google Earth.

Figure 5. A schematic section representing the stratigraphy of the Uruq Al Hadd Area, Rub Al Khali, Western Oman, the section is combined from various smaller sections in the area of interest.

Figure 6. White marine limestone of the Dammam Formation overlain by epikarst fissure infillings and unconsolidated sand, $6.2 \mathrm{~km}$ due east of Maitan. Note the complex linear dunes in the background and the vegetation that covers the area. 
Figure 7. Both the white Eocene limestone and the chert nodules within them provided raw materials for the manufacture of lithic tools during the Palaeolithic and Neolithic in the area around Maitan (Scale bar is $20 \mathrm{~cm}$ ).

Figure 8. Cemented sand and pebbles infilling epikarst fissures developed in the Dammam Formation limestone, $6.2 \mathrm{~km}$ east of Maitan. Some of these features are pre-existing faults, as noted from the small displacement across their planes, which acted as fluid-conduit planes from the underlying artesian aquifers.

Figure 9. Cemented red sand and conglomerate of fluvial origin, $15 \mathrm{~km}$ north-north-west of Maitan, tentatively correlated to the Shisr Formation or Marsawdad Formation of possible Miocene-Pliocene age.

Figure 10. Consolidated aeolianite north of Maitan, the thickness of the aeolianite varies from place to place and the eroded surface on top of it can be richly endowed with Neolithic tools, ornaments and some fauna.

Figure 11. Areally extensive but thin gypsiferous silty « playa » deposits (sabkha) with polygonal shrinkage cracks occur widely in the interdune « Urg or Shaq » of the Rub Al Khali. These deposits are seldom more than a metre thick.

Figure 12. Semi-consolidated, well-bedded aeolian sand cemented by gypsum and overlain by remnants of a mound of gypsiferous silt/clay (SQJ-2).

Figure 13. Dark brown sand with " desert roses " associated with pale gypsum deposits. The height of the gypsum structure is about $40 \mathrm{~cm}$. These " desert roses » (sandy gypsum crystals) occur in the sands beneath widespread gypsiferous clay/silt deposits (Site SQJ-6). 
Figure 14. Gypsiferous clay/silt mound with rhizoliths overlying semi-consolidated aeolian sand (SQJ-1).

Figure 15. Gypsiferous clay/silt mound overlying semi-consolidated aeolian sand and a large bifacial tool with adhering gypsum crust (inset) (near SQJ-4). These mounds could represent the sites of springs (scale bar in the inset photo is $5 \mathrm{~cm}$ ).

Figure 16. Circular, concave-up silt drape overlying unconsolidated dune sand, $40 \mathrm{~km}$ northnorth-east of Maitan, the result of a single rain storm flooding an interdune depression, with subsequent removal of the adjacent dune by aeolian activity and sand deposition within the depression leaving the raised edges emergent. These deposits tend to be eroded rapidly and may disappear within a few years of their formation.

Figure 17. Immense linear dunes cover about $50 \%$ of the land surface in the Rub Al Khali. Overall, the dunes are relatively immobile, but their surface topography changes on a daily basis. Shown is a limb of a large star dune, part of a linear dune complex more than $50 \mathrm{~km}$ long. The interdune area in the middle is part of the Shaq Shuayt interdunal system, where a concentration of Late Palaeolithic tools occurs.

Figure 18. Large cowrie shell, Cypraea grayana, from SQJ-8, utilised as an ornament (dorsal part removed). A) stereo ventral view, B) stereo dorsal view (note the thin coating of aeolianite inside the shell) (scale: $10 \mathrm{~mm}$ ).

Figure 19. Small Cypraea shell, stereo ventral view, utilised as an ornament (dorsal part removed) from SQJ-2 (scale: $10 \mathrm{~mm}$ ). 
Figure 20. Stereo views of small marine snails from SQJ-8, some of which are coated and infilled with indurated dune sand. A-D) Cypraea spp. shells, E) Indeterminate dorsal part of shell, F) eroded Morula granulata (1 - dorsal views; 2 - ventral views) (scale: $10 \mathrm{~mm}$ ).

Figure 21. Stereo images of marine shells associated with Neolithic implements at SQJ-8. A) Cypraea sp. (A1 - ventral view, A2 - dorsal view); B) Oliva bulbosa, (B1 - ventral view, B2 - dorsal view); C) oblong wedge of ribbed bivalve, probably Chlamys sp. (C1 - outer surface, C2 - inner surface) (scale: $10 \mathrm{~mm}$ ).

Figure 22. Stereo views of marine molluscs from SQJ-2. A) oblong wedge of bivalve shell, B) fragment of Cypraea sp. C) Nerita textilis, D-G) Volvarina spp. H-I) Ancilla ovalis (1 - dorsal views, 2 - apertural views except for $\mathrm{C} 1$ and $\mathrm{C} 2$ and $\mathrm{I} 1$ and 12 which are apertural and dorsal views respectively) (scale: $10 \mathrm{~mm}$ ).

Figure 23. Stereo images of seashells Urq Shuayt.A) fragment of degraded nacrous bivalve shell (1 - outer surface, 2 - inner surface); B) Nerita albicilla, (1 - dorsal view, 2 - ventral view); C) Chlamys sp. (1 - outer surface, 2 - inner surface) (scale: $10 \mathrm{~mm}$ ).

Figure 24. Stereo views of a shell fragment of Chlamys from SQJ-2. A) outer surface, B) inner surface (scale: $10 \mathrm{~mm}$ ).

Figure 25. Stereo images of cypraeids and bivalve shells near SQJ-4. A-F) Cypraea spp. (1 - ventral views, 2 - dorsal views) A and E are broken; G-H) fossil Chlamys sp. (1 - outer surfaces, 2 - inner surfaces) (scale: $10 \mathrm{~mm}$ ).

Figure 26. Stereo images of a button-like object manufactured from a marine bivalve shell, possibly Anadara sp. from the area near SQJ-4. (A - outer surface, B - inner surface) (scale: 10 $\mathrm{mm})$. 
Figure 27. Stereo images of a bead from the area near SQJ-4, made from a small fossilised sea urchin. A) ventral view, B) dorsal view (scale: $10 \mathrm{~mm}$ ).

Figure 28. Stereo views of an ornament made from a fragment of bivalve shell. A) outer side (note shallow linear groove worn between the two notches and the vertical shell microstructure), B) inner view (note the horizontal shell microstructure and a sinuous ridge traversing from top to bottom in the middle of the object) (scale: $10 \mathrm{~mm}$ ).

Figure 29. Eggshell fragment from locality SQJ-2.5 which is $2.6 \mathrm{~mm}$ thick, possibly representing the extinct ostrich species Diamantornis laini, A) strongly eroded/dissolved outer surface, B) slightly dissolved inner surface (scale: $10 \mathrm{~mm}$ ).

Figure 30. Fossil eggshell fragments from SQJ-1, attributed to Struthio camelus. Top row - external surface, bottom row - internal surface (scale: $10 \mathrm{~mm}$ ).

Figure 31. Fossil eggshell fragments from SQJ-8, attributed to Struthio camelus. A) stereo views of external surface to show the pores, B) internal surface (scale: $10 \mathrm{~mm}$ ).

Figure 32. Univariate plots of struthious eggshell thickness. Only unweathered specimens were measured. Squares - unworked fragments, X - perforated eggshells. There is a clear preference to use thicker shells to manufacture beads.

Figure 33. Beads manufactured from ostrich eggshell, locality SQJ-2.9, Uruq Al Hadd. The doubly perforated button in the lower row at the left is made from a marine shell (see Fig. 10) (scale bar: $5 \mathrm{~cm})$. 
Figure 34. Bead shapers or arrow shaft straighteners made from limestone pebbles found in the area near SQJ-4 provide evidence that Neolithic people in Uruq Al Hadd may have manufactured their beads on site.

Figure 35. Stereo views of beads from the area near SQJ-4 manufactured from fossilised ostrich eggshell fragments. In A-C, the outer surfaces of the eggshells were partly dissolved before drilling took place, and some dissolution occurred after the beads were completed. In unfinished bead $D$, the inner surface of the eggshell has aeolianite adhering to it which has been drilled through by the bead maker, 1) outer surface, 2) inner surface (scale: $10 \mathrm{~mm}$ ).

Figure 36. Stereo views of a relatively unweathered ostrich eggshell bead from Uruq Al Hadd, Oman, outer (left) and inner (right) surfaces (scale: $10 \mathrm{~mm}$ ).

Figure 37. Chelonian scute from locality SQJ-2.9, Uruq Al Hadd, Rub Al Khali, Oman (scale: 10 $\mathrm{mm})$.

Figure 38. Lagomorph remains from Neolithic context, Uruq Al Hadd, Oman. A) distal humerus from locality SQJ-2.9 (A1 - caudal view, A2 - cranial view), B) stereo views of first phalanx from locality SQJ-1.2 (B1 - volar view, B2 - dorsal view) (scale: $10 \mathrm{~mm}$ ).

Figure 39. Small bovid remains from Neolithic sites in the Uruq Al Hadd. A) right talus from SQJ2, B) right talus from SQJ-4, C) right talus from SQJ-4, D) cuneiform C3 from SQJ-4, E) scaphoid from SQJ-2, F) cuneiform C3 from SQJ-2 (scale: $10 \mathrm{~mm}$ ).

Figure 40. Bivariate plot (external length: distal breadth) of bovid tali from Oman. The arrows show the lengths of incomplete fossil specimens. The grey oval for Neolithic specimens is estimated on the basis of the relation between external length and distal breadth of ruminant tali in general. The Neolithic specimens are clearly all smaller than the range of variation found in extant Omani goats and sheep. 
Figure 41. The formation of interdunal desert lakes in the eastern side of Rub Al Khali, following the cyclonic storm Mekunu that struck south-eastern Oman (Dhofar) at the end of May, 2018, covering great parts of eastern Rub Al Khali with a green lush that lasted a few months after the storm (Courtesy: Ahmed Al Touqi).

Figure 42. A large mound between SQJ-1 and SQJ-2 consists of semi-consolidated dune sand at the base, capped by a layer of gypsum nearly 1 metre thick. This could be the site of a former spring, now isolated as a mesa by erosion of the surrounding weakly consolidated sands. Neolithic artefacts occur on the top of the gypsum deposits, one being found attached to the gypsum.

Table 1. Terrestrial faunal remains associated with Neolithic tools in Uruq Al Hadd, 2019 collection (the numbers refer to quantity of fragments collected).

Table 2. Measurements (in $\mathrm{mm}$ ) of fossil lagomorph bones from the Neolithic site at Uruq Al Hadd, Oman.

Table 3. Measurements (in $\mathrm{mm}$ ) of small bovid tali from Oman. Fossils are from the Neolithic sites in the Uruq Al Hadd, the modern specimens are goats/sheep from Wadi Al Banah in North Oman.

Table 4. Measurements (in $\mathrm{mm}$ ) of post-cranial elements of bovids associated with Neolithic implements at Uruq Al Hadd, Oman. 